\title{
Establishment, Chemical Composition of Introduced Shrubs on Oklahoma Tallgrass Prairie
}

\author{
N.D. STIDHAM, J. POWELL, F. GRAY, AND P.L. CLAYPOOL
}

\begin{abstract}
On April 1, 1977, 14 species of containerized shrubs grown from seed in a greenhouse were transplanted onto North-Central Oklahoma tallgrass prairie to determine first-year growth and survival and fall utilization and forage quality of the shrubs. Plants of each species were transplanted onto Lucien loam (Udic Ustochrepts) and onto Grainola silt loam (Vertic Haplustalfs) soils. Grazing was permitted on one-half of the plants of all species during the fall. Growth and survival were greater on the more mesic Grainola soil, whereas utilization was greater on the more xeric Lucien soil. Early winter $\mathbf{N}, \mathbf{P}, \mathrm{K}$, and $\mathrm{Ca}$ contents and in vivo dry matter digestibility were two or three times greater in shrubs than in native herbaceous plants collected from the same area at the same time. Based on survival, growth, fall utilization and early winter forage quality, seven species deserve additional study under different soil, weather and management conditions. Atriplex canescens, Fallugia parad$o x a$, and Cowania mexicana var. stansburiana are the most promising winter browse plants for Oklahoma tallgrass prairies.
\end{abstract}

Because of decreasing acreage of Oklahoma rangeland and increasing demand for meat, there is increasing production pressure on rangelands. To increase meat production on rangelands, not only must forage quality and carrying capacity be increased, but the period of adequate forage quality needs to be extended.

No forage class (i.e., grass, forbs, shrubs) maintains a high nutritional level throughout the year. Most forage plants are high in nutritive value during early growth but their forage value declines rapidly as they mature. Browse plants have a relatively high level of crude protein throughout the year (Dietz 1972). However, crude protein, phosphorus, and carotene levels decrease with plant maturity while calcium and fiber components increase. In general, shrubs contain higher percentages of crude protein but lower digestible energy during fall and winter than grasses or forbs (Cook and Harris 1968, Cook 1972).

Rangelands with more diverse vegetation are often more suitable for common use by several kinds of livestock and wildlife than for single use by only one kind of animal (Bell 1969, Cook 1954, Dusek 1975, Merrill and Young 1954). Establishment of adapted browse plants in tallgrass prairies would increase rangeland fall and winter carrying capacity for livestock as well as plant species and diet diversity. Therefore the objective of this study was to determine the first year summer survival and growth and fall

\footnotetext{
Authors are graduate research assistant, professor of range science, professor of agronomy, and professor of statistics, Oklahoma State Univ., Stillwater 74078. Stidham is currently environmental specialist. Shell Oil Company. Houston. Texas.

This research is a contribution of the Oklahoma Agricultural Experiment Station as Journal Article No. 3631

Manuscript received August 22, 1980.
}

forage quality and utilization of selected introduced shrub species in a tallgrass prairie.

\section{Study Area}

The study area is located in North Central Oklahoma at coordinates $37^{\circ} 7^{\prime}$ latitude, $97^{\circ} 17^{\prime}$ longitude, and $22 \mathrm{~km}$ west of Stillwater, Okla. The elevation of the area is about $290 \mathrm{~m}$.

The area has a continental climate with an annual mean minimum temperature of $9^{\circ} \mathrm{C}$ and a mean maximum temperature of $22^{\circ} \mathrm{C}$. The average absolute minimum is $-14^{\circ} \mathrm{C}$ June through August. The annual precipitation averages $820 \pm 250 \mathrm{~mm}$. The average precipitation distribution during the 192-day growing season is 23\% (April-May), 34\% (June-August), and 19\% (September-October). The establishment sites were located in good condition tallgrass prairie vegetation previously used as a hay meadow or moderately grazed during the summer by steers.

The two soil types selected in the study area are on Shallow Prairie range sites with sandstone and shale parent material (Gray and Roozitalab 1976). Grainola silt loam is a fine, mixed, thermic Vertic Haplustalf. It is deep, well drained, and slowly permeable with a moderate water holding capacity. Lucien silt loam is a loamy, mixed, thermic, shallow Udic Ustochrept. It is shallow, well drained, and moderately rapid permeable with a low water holding capacity (Gray and Nance 1978).

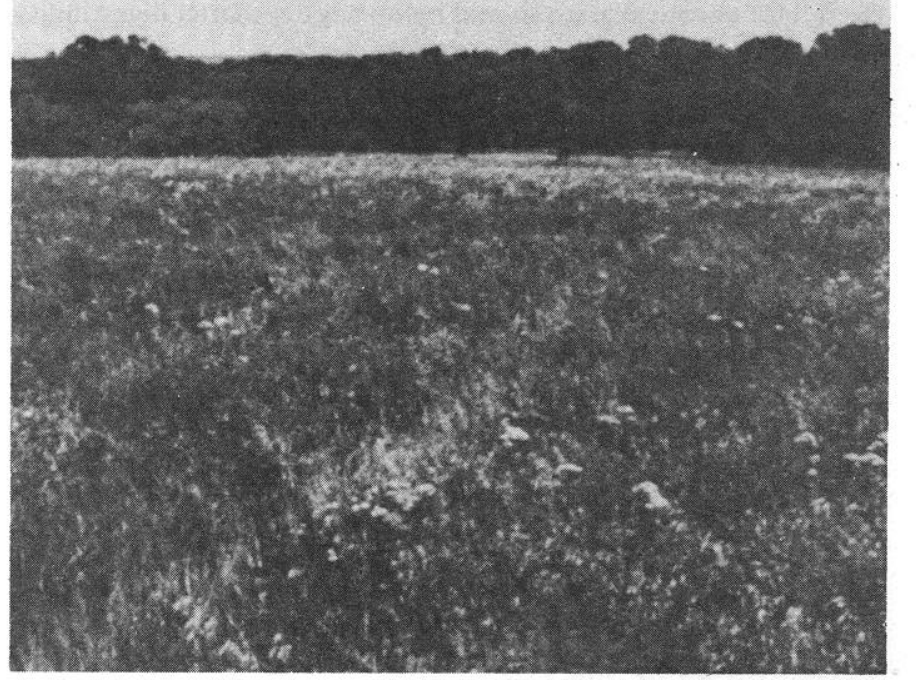

Fig. 1. View of study area. 
The vegetation on the Grainola soil is dominated by Andropogon gerardii, Schizachyrium scoparium, and Sorghastrum nutans. The vegetation on the Lucien soil is typical for shallow, xeric soil. Dominant species include Bouteloua gracilis, Bouteloua hirsuta, Bouteloua curtipendula, Bothriochloa saccharoides, and Bromus japonicus. A view of the study areas is shown in Figure 1.

\section{Methods}

On April 1, containerized seedlings, grown from seed in a greenhouse, of Purshia tridentata (PUTR). Atriplex canescens (ATCA), Ceanothus ovatus (CEOV), Artemisia tridentata (ARTR), Atriplex confertifolia (ATCO), Ceanothus velutinus (CEVE), Ceratoides lanata (CELA), Cercocarpus ledifolius (CELE), Cowania mexicana var. stansburiana (COME), Ephedra viridus (EPVI), Fallugia paradoxa (FAPA), Potentilla fructicosa (POFR), Ribes aureun (RIAU), and Ceanothus cuneatus (CECU) were removed from the greenhouse and transplanted in the study area. Artemisia frigida (ARFR) and Cercocarpus montanus (CEMO) plants were transplanted from southeastern Colorado in the study area at this time. Seed sources of other species are listed in Stidham (1978).

Plants of each species were planted on each of the two adjacent soil types. The bottom of each transplanted pot was removed and additional cuts were made in the side to facilitate root growth. Mid-range plant height was determined by measuring the height of the tallest and shortest plant in each plot. Plants were enclosed with mammal graze-proof wire cages to prevent grazing and watered periodically throughout the summer to minimize soil water stress.

On September 1 mid-range plant height was again determined for each species. The number of live plants in each pot was recorded. Summer plant growth was determined by subtracting April mid-range height from September mid-range height. Cages placed over one-half of the pots of each species on each soil type were removed at this time to allow grazing by cattle and wildlife. The different degrees of use by cattle and wildlife was not determined; however, all species browsed were observed to be browsed by cattle. Pots were also removed from around plants to reduce livestock curiosity.

On November 20, after freezing temperatures had stopped plant growth, mid-range plant height and number of live plants were determined for both grazed and ungrazed plants. Fall growth of ungrazed plants was determined by subtracting September midrange caged plant height from November mid-range caged plant height. Fall utilization was determined by subtracting November mid-range grazed plant height from November mid-range caged plant height. Species survival was determined by subtracting the number of live plants in November from the number of live plants in April. Current twig and leaf growth was collected in November as three composite samples per species from plants caged through the fall for chemical analysis and nylon bag dry matter digestibility (NBDMD).

Plant samples were dried at room temperature $\left(25^{\circ} \mathrm{C}\right)$ to a constant weight, ground in Wiley mill with a $2-\mathrm{mm}$ mesh screen, and analyzed for kjeldahl nitrogen, phosphorus, potassium, and calcium (OSU Soil and Water Testing Laboratory, Unpublished procedures). Dry matter content (\%) was determined by heating duplicate 2-gram samples for 24 hours at $100^{\circ} \mathrm{C}$. Two rumenfistulated steers were used for NBDMD determinations (Johnson 1966). A 3-gram aliquot of each sample was placed in each steer for 48 hours. Samples were removed from steers, washed, dried at $60^{\circ} \mathrm{C}$ for 48 hours and reweighed to determine NBDMD.

Statistical comparisons for plant growth, utilization, and species survival were made by species and between soil types. Soil types were not replicated. Statistical comparisons for plant chemical composition and NBDMD were made by species. All differences discussed were significant at the $5 \%$ level of probability unless otherwise specified.

\section{Species Growth by Soil Type}

\section{Results and Discussion}

Summer plant growth varied among species and between soil

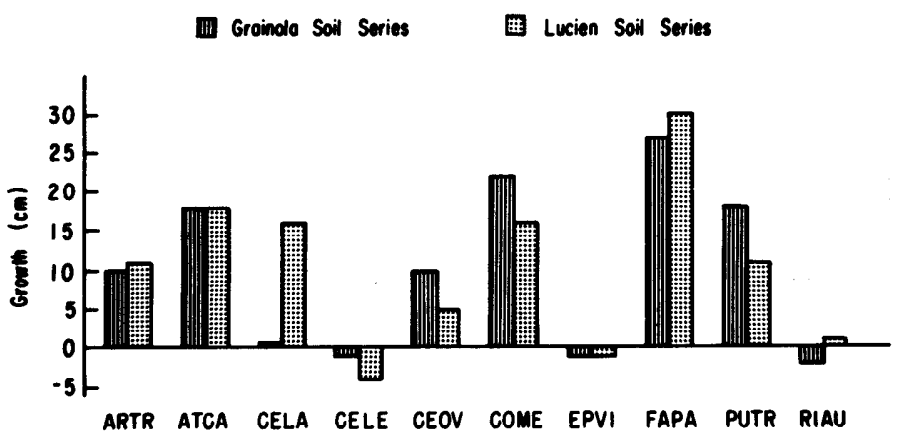

Fig. 2. Average mid-range growth (cm) of 10 introduced shrub species on the two soils. Negative growth indicates terminal portion of stems died during the summer.

types (Fig. 2). Growth ranged from 1 to $30 \mathrm{~cm}$ depending upon the species. ARTR, ATCA, and FAPA growth was not affected by soil type. Apparently these species are equally adaptable to both soils. However, FAPA flowered on the more mesic Grainola soil, but not on the Lucien soil.

CELE, EPVI and RIAU plants failed to grow well on either soil type. The growing points on twigs of these species died during the summer. EPVI twig tips dried and became brittle in late July. Leaves of RIAU turned brown and fell from plants on both soil types by early July. However, after a rain in mid August and several days of cooler temperatures, some RIAU plants on the Lucien soil produced new leaves. New leaves appeared on RIAU plants on the Grainola soil in September. The more readily available soil water in the Lucien soil was probably responsible for the earlier leaf production of RIAU.

ARFR plants on the Lucien soil produced seed whereas plants growing on the Grainola soil did not. Seed production may have been induced by the more xeric Lucien soil. CEMO plants were pruned before transplanting. Plants on both soil types produced very little woody stem growth but an abundance of leaves where stems were cut.

CELA, CEOV, COME, and PUTR growth was affected by soil type. CELA growth was $15 \mathrm{~cm}$ greater for plants growing on the xeric, Lucien soil. CELA plants never attained an erect growth form or developed strong woody stems characteristic of this species.

CEOV, COME, and PUTR plants growing on the Grainola soil exhibited growth of $100 \%, 63$, and $37 \%$, respectively, greater than plants of these species growing on the Lucien soil. The increased plant growth was probably due to the greater water holding capacity of the Grainola soil. Differences in growth of CELA, CEOV, COME, and PUTR due to soil type indicate these species have particular requirements which influence adaptability. Fall growth was negligible for all species studied.

\section{Species Utilization by Soil Type}

Utilization differences were greater among species than between soil types (Fig. 3). Utilization ranged from 0 to $23 \mathrm{~cm}$ of vegetative growth depending upon the species.

Browsing of CEMO, CEOV, and FAPA was greater on the shallower Lucien soil. Plants growing on shallower soils are often more leafy and produce smaller stems than the same species growing on deeper soils (Cook 1959). Stem:leaf ratios were not determined in this study. Utilization was not correlated with plant height growth.

Utilization of ARFR, ARTR, ATCA, EPVI, and RIAU was not affected by soil type. Appa rently soil type did not influence palatability to the extent that animals preferred plants growing on one soil type over the other. PUTR utilization was $50 \%$ greater on plants on the Grainola soil than plants on the Lucien soil. Due to 


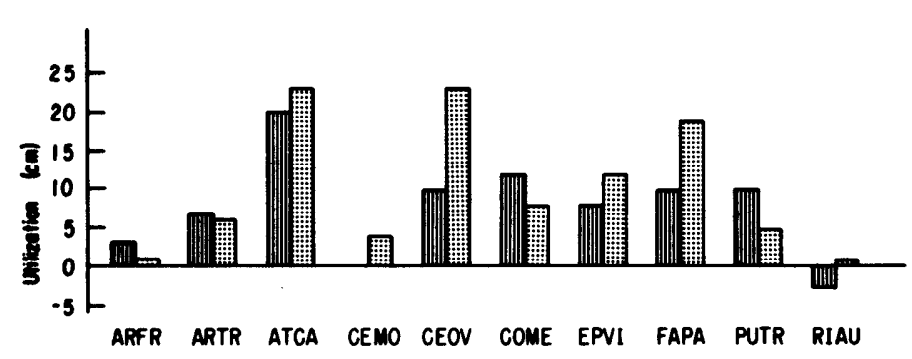

Fig. 3. Average fall utilization (cm) of 10 introduced shrub species on two soils. Utilization $=$ November caged plant height - November grazed plant height.

the small sample (plants/soil type) size, comparisons of utilization by soil may not be a true indication of preference.

\section{Species Growth, Survival, and Utilization}

Species growth, survival, and utilization, averaged for both soils, varied greatly among species (Fig. 4). Average mid-range growth ranged from $7 \mathrm{~cm}$ for CEOV to $30 \mathrm{~cm}$ for FAPA. ATCA, COME, FAPA, and PUTR produced mean growth of $15 \mathrm{~cm}$ or more. ARTR, CELA, CEOV, and EPVI grew less than $15 \mathrm{~cm}$.

ATCO, CEVE, POFR, and CECU failed to survive the summer. Apparently climatic differences between the study area and the native habitat of these species were too great for survival even though the plants were watered. No common habitat requirements or limitation for these four species could be determined from the literature.

Species survival through the summer ranged from a low of $29 \%$ for CEOV to a high of $100 \%$ for ARFR and CEMO. Well developed root systems of ARFR and CEMO when transplanted, probably enabled them to survive the higher summer temperatures and soil water stress. ARTR, CEOV, and COME survival was less than $50 \%$, whereas, survival of ARFR, ATCA, CELA, CEMO, EPVI, FAPA, and PUTR was $50 \%$ or greater.

Utlization of ARFR and CEMO was relatively low. Utilization of new growth was approximately $50 \%$ for ARTR, COME, FAPA, and PUTR. Both leaves and stems of ARTR were browsed. Often entire plants were stripped of their leaves.

ATCA utilization exceeded new growth by $5 \mathrm{~cm}(31 \%)$. Not only was new growth consumed but part of the original plant growth was eaten. All ATCA plants were heavily utilized. Most of the CELA plants scheduled to be grazed died. Consequently there were too few CELA plants to accurately determine utilization. Utilization of CEOV plants exceeded new growth by $9 \mathrm{~cm}(125 \%)$. Many plants were either chewed off at ground level or missing. EPVI plants failed to produce new growth but almost all old growth was consumed.

\section{Plant Chemical Composition and Digestibility}

November nitrogen content in the various species ranged from 0.89 to $2.5 \%$, phosphorus 0.07 to $0.23 \%$, potassium 0.52 to $1.48 \%$, and calcium 0.58 to $1.99 \%$ (Fig. 5). The high nitrogen content in CEMO plants may be due, in part, to the high percentage of leaves in the sample. This species produced very little woody stem growth but an abundance of leaves. At the time of sampling, leaves were greenish brown in color, flexible, and intact. This species appears to have a greater cold tolerance than other species; therefore translocation of nutrients from leaves to stems may occur later in the season. There was insufficient plant sample to determine nitrogen content of CEOV and CELA. The nutrient content of study species were greater than nutrient levels in herbaceous samples collected in the study area. Mean nutrient contents for study species were $1.39 \%$ nitrogen, $0.16 \%$ phosphorus, $0.94 \%$ potassium, and $0.99 \%$ calcium. Mean nitrogen content of prairie hay samples cut at the same time was $0.57 \%$. Phosphorus, potassium, and

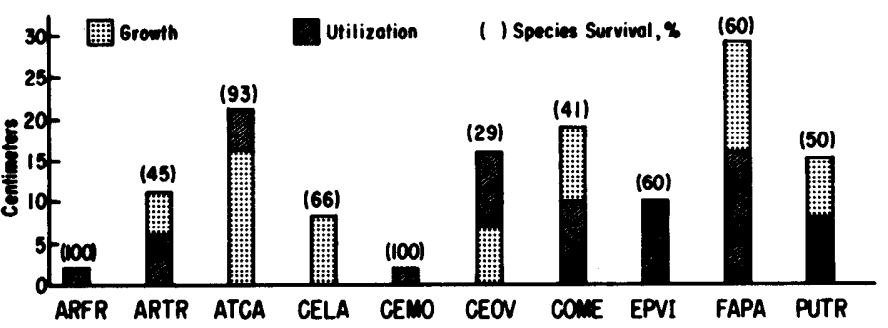

Fig. 4. Average summer growth $\left(L S D_{.05}=3.8 \mathrm{~cm}\right)$, fall utilization $\left(L S D_{.05}=\right.$ $4.0 \mathrm{~cm})$, and survival ( $L S D_{.05}=11 \%$ ) of 10 introduced shrub species on both soils. Initial transplanted growth plus new growth was consumed where utilization exceeded growth.

calcium levels of forage cut at the same time from a comparable area were $0.04 \%, 0.36 \%$, and $0.44 \%$, respectively.

The five species analyzed for NBDMD were relatively digestible for dormant plants, and the variation in NBDMD was less than that for chemical composition. Digestibility ranged from 46 to $53 \%$ (Fig. 6). Mean NBDMD of the five species analyzed was $49 \%$. Digestibility of herbaceous forage samples collected from the study area at the same time was only $22 \%$. There was not enough plant sample to determine NBDMD for ARFR, CEMO, EPVI, RIAU, CEOV, or CELA.

\section{Conclusions}

Plant growth and survival for most species were greater on the more mesic Grainola soil, while utilization was usually greater on the xeric Lucien soil. ARTR, ATCA, and FAPA growth was not affected by soil type and these species have good potential as browse plants in the tallgrass prairie. ARFR and CEMO also seem to be potential browse plants in this area. CELE, EPVI, and RIAU did not grow well on either soil type and their successful establishment and growth are doubtful. ATCA, CEMO, FAPA, and PUTR made the greatest growth. ATCA, CEOV, and FAPA were the most heavily browsed and would increase diet diversity. ARFR, CEMO, ATCA, CELA, and FAPA had the highest survival percentage.

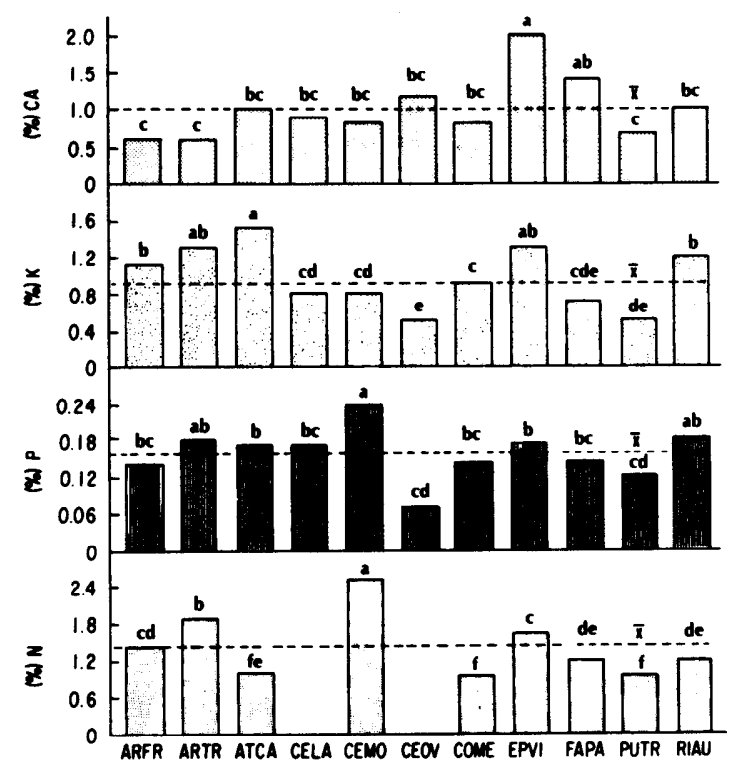

Fig. 5. Average $(\mathrm{X} \pm \mathrm{S}$.D.) November nitrogen $(N)$, phosphorus $(P)$, potassium (K), and calcium (CA) contents (\%) in II introduced shrub species. Those values for the same nutrient with the same letter are not significantly different at the 0.05 level. 


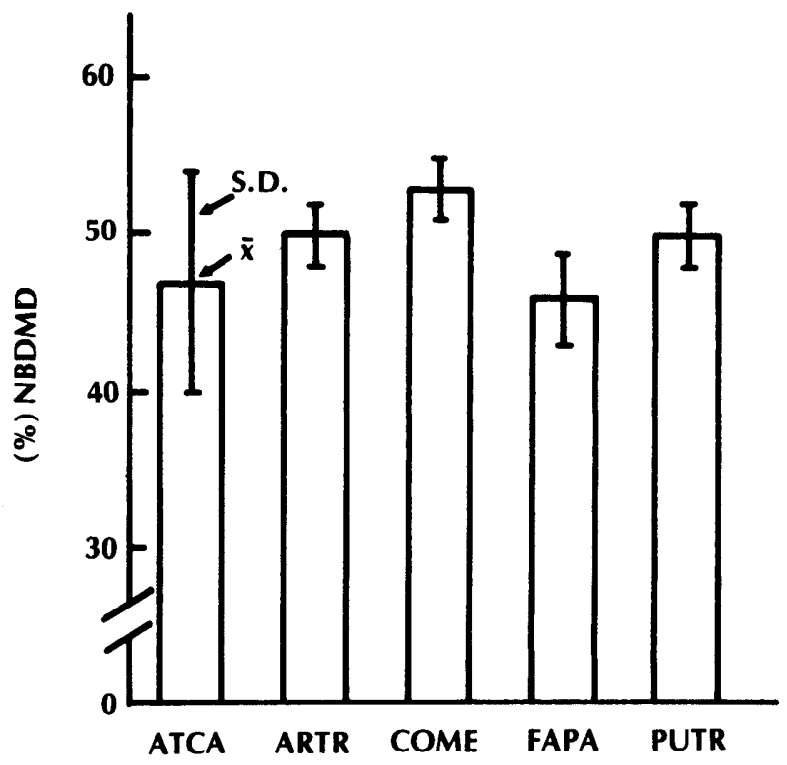

Fig. 6. Average (X \pm S.D.) November nylon bag dry matter digestibility (NBDMD) for 5 shrub species.

Based on growth, utilization, survival, and chemical composition, further work towards establishment of ATCA and FAPA in tallgrass prairie is recommended to provide additional sources of supplemental nutrients in the fall and winter.

\section{Literature Cited}

Bell, R.H.V. 1969. The use of the herb layer by grazing ungulates in the Serengeti. p. 111-123. In: A Watson(ed.). Animal populations in relation to their food resources, a symposium of the British Ecological Society (Aberdeen). Blackwell Sci. Pub., Oxford.

Cook, C.W. 1959. The effect of site on the palatability and nutritive content of seeded wheatgrasses. J. Range Manage. 12:289-292.

Cook, C.W. 1972. Comparative nutritive values of forbs, grasses and shrubs. p 303-310. In: Wildland shrubs-their biology and utilization. U.S. Dep. Agr. Forest Serv. Gen. Tech. Rep. INT-1. 494 p.

Cook, C.W., and L.E. Harris. 1968. Nutritive value of seasonal ranges. Utah Agr. Exp. Sta. Bull. 472. 55 p.

Dietz, D.R. 1972. Nutritive value of shrubs. p. 289-302. In: Wildland shrubs-their biology and utilization. U.S. Dep. Agr. Forest Serv. Gen. Tech. Rep. INT-1. 494 p.

Dusek, G.L. 1975. Range relations of mule deer and cattle in prairie habitat. J. Wildl. Manage. 39:605-616.

Gould, F.W. 1968. Grass systematics. McGraw-Hill Book Company, Inc., New York. 382 p.

Gray, F., and E. Nance. 1978. Lake Carl Blackwell experimental range area soil survey. Oklahoma Agr. Exp. Sta. Rep. p. 763.40 p.

Gray, F., and M.H. Roozitalab. 1976. Benchmark and key soils of Oklahoma. Oklahoma Agr. Exp. Sta. MP-97. 36 p.

Johnson, R.R. 1966. Techniques and procedures for in vitro and in vivo rumen studies. J. Animal Sci. 25:855-75.

Merrill, L.B., and A. Young. 1954. Results of grazing single classes when stocking rates are constant. Tex. Agr. Exp. Sta. Prog. Rep. 1726. 6 p.

Stidham, N.D. 1978. Germination, establishment, growth, utilization, and chemical composition of introduced shrubs on North Central Ok lahoma rangeland. M.S. Thesis, Oklahoma State Univ., Stillwater. 95 p. 